Teknomekanik

Vol.4, No.1, May 2021, pp. 1 7

e-ISSN: 2621-8720 p-ISSN: 2621-9980

\title{
Performance Analysis of Water Heating System by Using Double Glazed Flat Plate Solar Water Heater
}

\author{
Andika Putra, Arwizet K, Yolli Fernannda and Delima Yanti Sari
}

Department of Mechanical Engineering, Faculty of Engineering, Universitas Negeri Padang, Padang 25131, Indonesia

\section{Article Info \\ Article history: \\ Received Nov $05^{\text {th }}, 2020$ \\ Revised Jan $17^{\text {th }}, 2021$ \\ Accepted Mar 25 ${ }^{\text {th }}, 2021$}

\section{Keywords:}

Solar Energy

Solar Collector

Solar Water

Double Plate Heater

Water Heating

\begin{abstract}
Nowadays, the use of solar energy is incredibly important to be increased since solar energy is renewable energy and also does not cause pollution. To harness solar energy, a solar collector device is needed to convert solar energy into heat energy. This study aimed to analyze the heat transfer in the flat plate solar collector which is used as a source of thermal energy in the water heating process for bathing. A double-glazed solar collector was used to absorb solar thermal energy and then transferred it to a water pipe. The pipe material used copper which has a very high conductivity value with an outer diameter of $15.7 \mathrm{~mm}$. The plate collector used aluminum plates because they have high thermal conductivity. The dimensions of the collector frame were $150 \mathrm{~cm}$ long, 80 $\mathrm{cm}$ wide and $80 \mathrm{~cm}$ high. The collector frame was made of wood and covered with an insulator from coconut fiber with a thickness of $8 \mathrm{~cm}$, with a tilt angle of $15^{\circ}$. Based on the experimental process, the collector temperature was taken by using a thermocouple to heat the water which the inlet temperature in a bucket was $28^{\circ} \mathrm{C}$ and the outlet water temperature during the experiment was $40^{\circ} \mathrm{C}$.
\end{abstract}

Corresponding Author:

Andika Putra

Department of Mechanical Engieering, Faculty of Engineering, Universitas Negeri Padang,

Jln. Prof. Dr. Hamka Air Tawar, Padang 25131, Sumatera Barat, Indonesia

Email: dika123097@gmail.com

\section{INTRODUCTION}

Solar energy is radiation energy that is produced by the sun which is incredibly important with an enormous heat potential to do various things so that it can be harnessed by Indonesian people generally [1]. One of the technologies for collecting and storing solar energy is utilizing solar thermal energy as alternative energy [2]. Solar thermal energy is beneficial to heat the water that people use for bathing purposes with the help of Solar Water Heater [3]. Solar thermal is the utilization of energy obtained from shortwave solar radiation [4], which is then transferred to the heat carrier medium through a solar collector [5]. Solar thermal energy can also be utilized on a larger scale, such as high-temperature water for steam production and electricity generation [6]. In general, types of solar thermal collectors can be categorized into 4 types, namely concentrated solar collectors, evacuated tube solar collectors, passive solar collectors, flat plate solar collectors [7]. Flat plate solar collectors are most commonly employed in solar water heating systems in residential buildings for indoor space heating and hot water production [8]. In this research, a flat plate solar collector made of aluminium was made corrugated and painted in black so that the absorption of solar radiation emitted by the sun obtained great heat results [9]. Flat plate solar collector is one of the types that is often used to heat water since it gained maximum heat results [10]. A flat plate solar collector can be harnessed to capture solar thermal energy and the heat is transmitted to pipes filled with water so that the temperature of the water in the pipe increases [11]. A cover glass is needed as a medium for receiving direct radiation rays from the sun, an absorber is used as a medium to absorb heat that has been received by the cover glass, and an insulator as a medium is useful for holding back the waste of heat that has accumulated in the heating collector [12].

The component of a flat plate solar collector consists of a black surface as an absorber of solar radiation energy which is then transferred to a copper pipe [13]. Glass cover plays the role to reduce radiation effects 
and convection losses to the atmosphere [14]. The pipes are used to drain the fluid to be heated and insulation to reduce conduction losses to the environment [15]. Collector performance is stated by energy balance which describes the distribution of incoming solar energy to useful energy and energy loss [16]. The working principle of a solar water heater using a flat plate is water which enters the collector through a distributor pipe will be heated through direct solar radiation or convection [17]. It occurs because the solar radiation energy in the collector is limited by transparent glass, resulting in heat transfer to the distributor pipes which causes the temperature of the water in the pipe to increase directly and this also results in density differences [18]. High-temperature water and low-temperature water have an inversely proportional density in which high-temperature water has a lower density which causes it tends to flow to a higher direction while lowtemperature water has a higher density so it tends to move downward causing natural convection [19]. In general, the flat plate solar collector consists of the main parts, namely absorber plate, copper pipes, transparent glass cover, thermal insulation and frame assembly.

The material used to transfer the heat is copper pipes. Copper pipe can drain water with a larger volume so that it facilitates contractors to install pipes on a double glazed solar water heater [20]. Moreover, the copper pipe can bend and requires fewer collectors and fasteners, thus saving installation costs. Therefore, the copper pipe was chosen as a material due to its advantages as follows: 1) Strong so that it is resistant to vibration, pressure, and vacuum; 2) Leak-proof and rust-resistant; 3) Durable; 4) Weatherproof and ultraviolet rays resistant, so it can be adapted for outdoor applications; 5) Easy to replace and repair if there is damage [21]. The purpose of this study was to design a heat transfer device as an effort to improve solar thermal efficiency using flat plate solar thermal and to determine the effect of solar radiation intensity on useful energy and energy losses generated by solar water heating collectors with double glazed flat plate solar water heater, as well as convection heat transfer coefficient between absorber plate and water.

\section{METHODS}

The research method used in this study was experimental research by utilizing solar thermal energy as a means of heating water through a heat transfer device installed on a solar collector. This device was called a thermal collector which was used to heat water when it received heat energy from the sun [22]. The design of the thermal collector used a flat plate measuring $100 \mathrm{~mm}$ x $80 \mathrm{~mm}$. The thermal collector pipe used copper material with a diameter of $12.7 \mathrm{~mm}$ and a diameter of $15.7 \mathrm{~mm}$. The temperature readings in this device used a HUATO S220-T8 thermocouple sensor and Dekko Corporation Korea Thermocouple sensor cable [23]. The steps of the research process can be seen in Figure 1 [24].

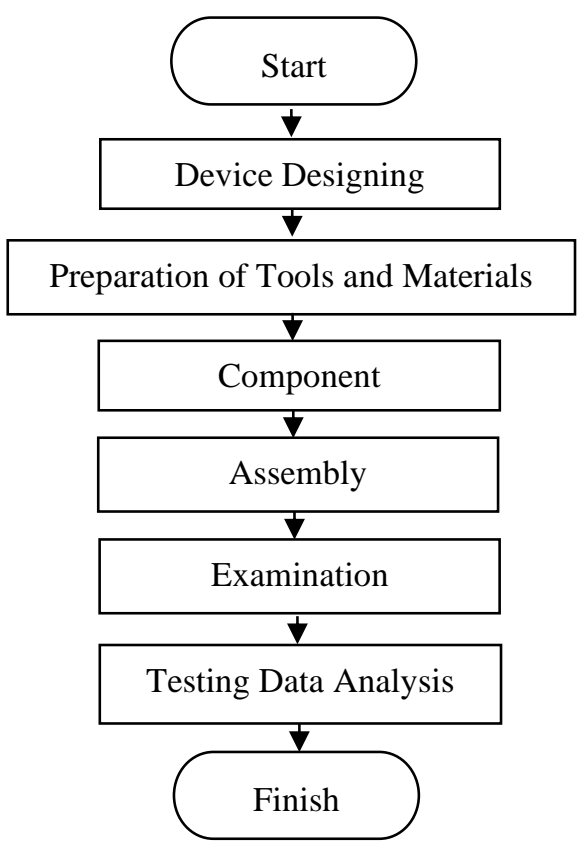

Figure 1 : The steps of the Research Process

The result of the manufacture was in the form of device design dimensions of the Double Glazed Flat Plate Solar Water Heater in which the overall length of $150 \mathrm{~cm}$, the height of the front surface of $30 \mathrm{~cm}$ and 
the rear surface of $80 \mathrm{~cm}$, the width of $80 \mathrm{~cm}$, the thickness of the glass $5 \mathrm{~cm}$, the distance between the pipes of $10 \mathrm{~cm}$, and the tilt angle of the device of $15^{\circ}$ can be seen in Figure 2.

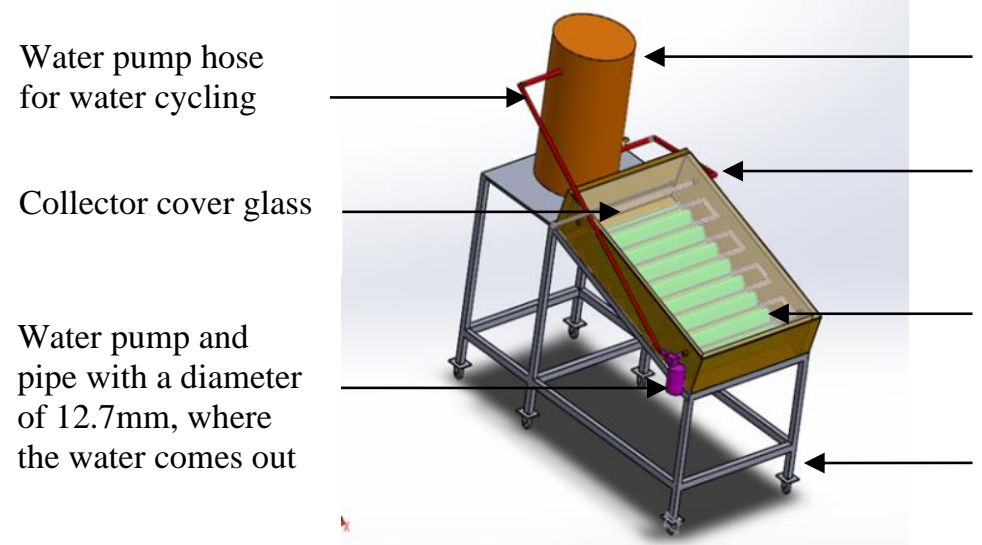

Figure 2 : Double Glazed Plate Solar Water Heater
The bucket for initial reservoir

Pipe Diameter 15,7 $\mathrm{mm}$, the place for initial water

Zig-zag grooved pipe

Double glazed plate solar water heater framework

This research focused on the ratio of the temperature rise $\left(T_{\text {in }}\right)$ and $\left(T_{\text {out }}\right)$ in the double glazed solar water heater, which can be seen that the power of the heat-conducting medium absorbed the heat temperature from the solar thermal collector to heat water in copper pipes. To obtain the hot temperature, the temperature reading was placed in some points namely at $\mathrm{T}$ out, $\mathrm{T}$ in, and under the plate. The first step, the researcher prepared the device by placing it under the sun, thermocouple, and laptop. The second step each thermocouple sensor was placed at a predetermined temperature reading point. Then, the researcher opened the water tap and paid attention to the temperature rise on the laptop every 10 minutes for 4 hours from 11 am until $2 \mathrm{pm}$. The same steps were carried out for the three days of the experiment. The useful energy gain for heating the fluid through the collector $\left(Q_{u}\right)$ can be determined by multiplying the mass flow rate of fluid $(m)$, the specific heat of the fluid $\left(C_{p}\right)$ and the difference of the outlet temperature with the inlet temperature (Equation 1). After the fluid heat value was obtained, the next step was to measure the value of collector efficiency $(\eta)$ which defines as the useful energy gain of the fluid passing through the collector $\left(Q_{u}\right)$ divided by the radiation energy at the collector area $\left(Q_{A b s}\right)$ multiplied by $100 \%$ [25].

$$
\begin{aligned}
& \mathrm{Q}_{\mathrm{u}}=\mathrm{m} \cdot \mathrm{C}_{\mathrm{p}} \cdot\left(\mathrm{T}_{2}-\mathrm{T}_{1}\right) \\
& \eta=\frac{Q_{u}}{Q_{A b S}} 100(\% \ldots . .
\end{aligned}
$$

\section{RESULTS AND DISCUSSION}

The data taken in the research of solar collector testing on double glazed solar water heaters contain some data consisting of solar radiation intensity $\left(\mathrm{I}_{0}\right)$, inlet water temperature $\left(\mathrm{T}_{1}\right)$, outlet water temperature $\left(\mathrm{T}_{2}\right)$, absorber plate temperature $\left(\mathrm{T}_{3}\right)$ and ambient temperature $\left(\mathrm{T}_{4}\right)$. The data were taken using a thermocouple sensor temperature reader. Data recording was carried out every 10 minutes. From the data of the test results, the data obtained can be made a graph of the intensity of solar radiation during the test data collection in Figure 3.

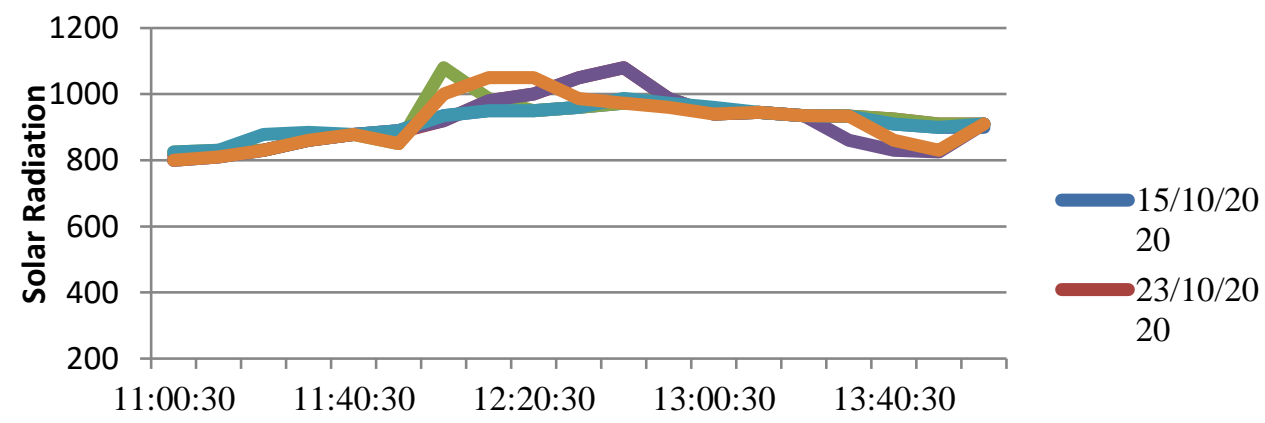

Figure 3 : The Graph of Daily Solar Radiation Intensity against Data Collection Time 
In Figure 3, it was shown more specifically that the maximum data value was obtained during the research period on 23 and 26 November 2020 at 12.00 to 13.00 with the maximum value of solar radiation was $1050.82 \mathrm{Watt} / \mathrm{m} 2$. Whereas, the minimum results of research data recording on the first day due to the weather was a bit cloudy with a maximum value of only $900.43 \mathrm{Watt} / \mathrm{m} 2$. Daily solar radiation recorded with lux meter data during testing was quite varied. The first data recording was taken at 11.00 until 14.00. Data were taken every 10 minutes and each solar radiation had the same pattern, namely, it was low at the beginning and changed in increasing gradually until it reached the maximum point. Then the intensity of solar radiation began to decline nearing the minimum point at the end of the research. It was caused by the rotation of the earth on its axis or the rotation of the earth on its axis caused each region to experience a day and night cycle. The relationship between the inlet water temperature and the outlet water temperature with time can be seen in figure 4.

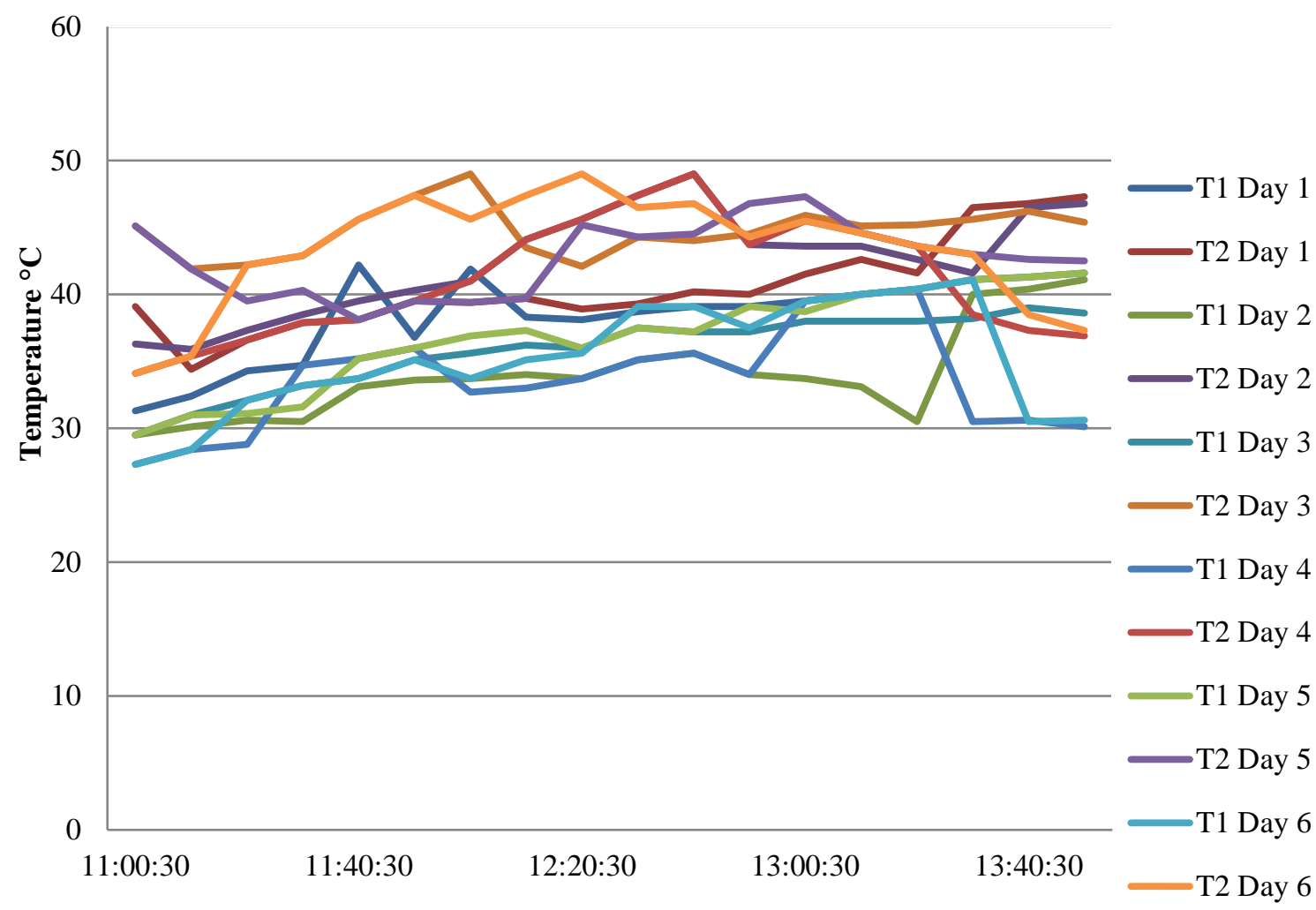

Figure 4 : The graph of the relationship between Time and Temperature of Inlet Water and Outlet Water on Double Grazed Plate Solar Heater Testing

From graph 4, it was seen that the temperature of the inlet and outlet water followed the solar radiation pattern according to the data collection time. As in general conditions, the temperature of the solar collector was measured by using a thermocouple for 6 days. Measurements were carried out every 10 minutes for 3 hours starting at 11.00 until 14.00. This temperature measurement was conducted to determine the extent of the temperature distribution obtained on the solar collector plate so that it could be seen the heat capacity possessed by the solar collector to transfer heat to the copper pipe with a water cycle. Based on the graphic, the temperature distribution in the first experiment was that the temperature circulates by having an increase in the initial temperature of the water temperature in the bucket $28^{\circ} \mathrm{c}$ at 11.00 with solar radiation intensity $800 \mathrm{w} / \mathrm{m} 2$ then at 10 minutes the water temperature started to rise with the outlet water temperature of $34.1{ }^{\circ} \mathrm{C}$ as solar radiation also increased. At 12.00 to 13.00 the inlet water temperature was $36.9{ }^{\circ} \mathrm{c}$ and the outlet water temperature was $46.8^{\circ} \mathrm{c}$. This temperature rise occurred due to the intensity of the sun at that hour rised high with solar radiation values range from $950 \mathrm{w} / \mathrm{m} 2$ to $973 \mathrm{w} / \mathrm{m} 2$. In the next hour, solar radiation began to fall, at which time the temperature of the outlet water started to decline $\left(42.5^{\circ} \mathrm{c}\right)$ along with the end of the research data collection. The form of temperature produced in the condition of sunny weather and average total radiation intensity in research data collection was on 27 and 30 October 2020. 

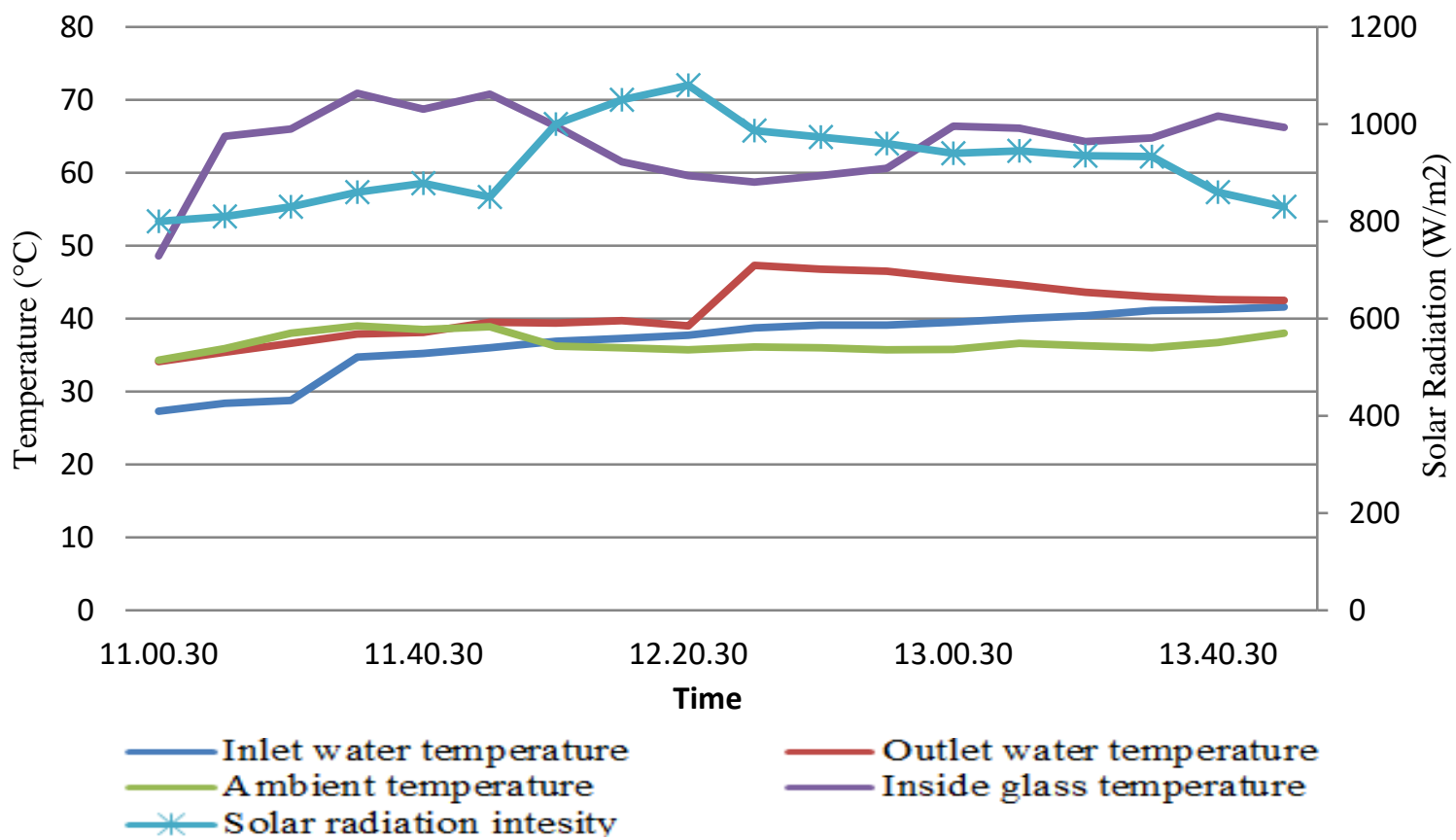

Figure 5 : Graph of the Average Intensity of Solar Radiation and Temperature obtained in the condition of Sunny Weather

The maximum average temperature in the condition of sunny weather was obtained in the research on 27 and 30 October 2020. The average temperature values were; total solar radiation intensity $1080 \mathrm{Watt} / \mathrm{m} 2$, initial temperature or temperature of water in a bucket $\left(\mathrm{T}_{\text {in }}\right) 39.1^{\circ} \mathrm{C}$, outlet water temperature $\left(\mathrm{T}_{\text {out }}\right) 46.8^{\circ} \mathrm{C}$, the temperature in the glass plate $\left(\mathrm{T}_{3}\right) 59.6^{\circ} \mathrm{C}$ and ambient temperature $\left(\mathrm{T}_{4}\right) 36^{\circ} \mathrm{C}$. The effect of the initial temperature variation can be seen in Figure 4.4 which in the first hour of taking research data, the inlet water temperature in the bucket was $29.5^{\circ} \mathrm{C}$ with a solar energy intensity value of $815 \mathrm{Watt} / \mathrm{m} 2$. Ten minutes later the hot weather gradually began to rise until it reached the intensity of the solar energy $825 \mathrm{Watt} / \mathrm{m}^{\circ} \mathrm{c}$ with the outlet water temperature or Tout $36.9^{\circ} \mathrm{C}$, ambient temperature $37.5^{\circ} \mathrm{C}$ and temperature in the glass plate $64.1^{\circ} \mathrm{C}$. The maximum temperature obtained at 12.00 to 13.10 with the intensity of solar radiation was from $920 \mathrm{Watt} / \mathrm{m} 2$ to $1080 \mathrm{Watt} / \mathrm{m} 2, \mathrm{~T}_{\text {in }}$ temperature $32.7^{\circ} \mathrm{C}$ and $\mathrm{T}_{\text {out }} 44.1^{\circ} \mathrm{C}$.

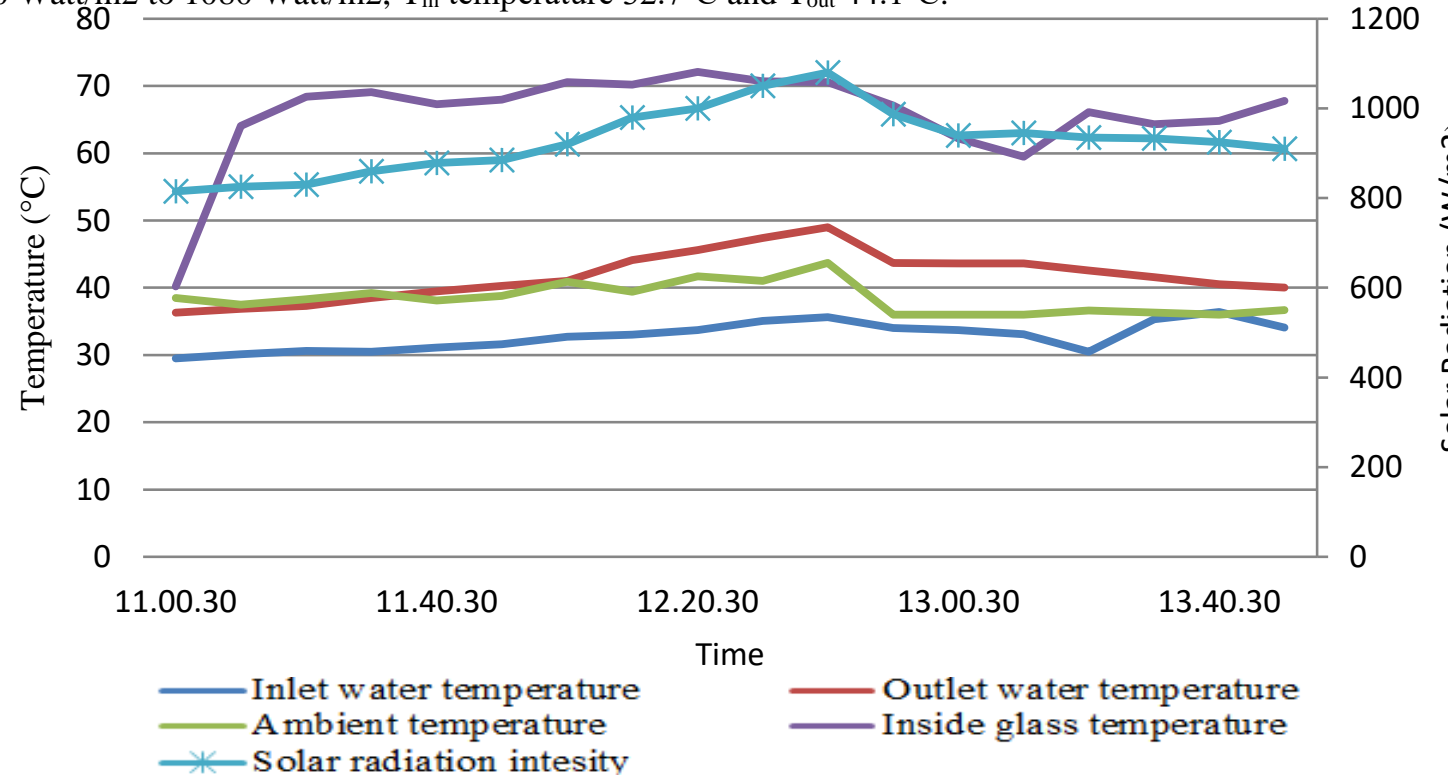

1200

更

Figure 6 : Graph of the Average Intensity of Solar Radiation and Temperature obtained in the condition of Partly Cloudy Weather 
On the experiment day on 23 and 28 October 2020, the condition was partly cloudy weather which can be seen in graph 6 . The initial value of the intensity of solar radiation was $800 \mathrm{Watt} / \mathrm{m} 2$, and the form of the research results was not much different in sunny weather conditions on graph 5 where the research was low at the beginning and gradually the temperature began to rise along with the increase in solar radiation at 12.00 until 13.20 then the temperature started to decline at 13.40 with the value of the intensity of solar radiation only $860 \mathrm{Watt} / \mathrm{m} 2$.

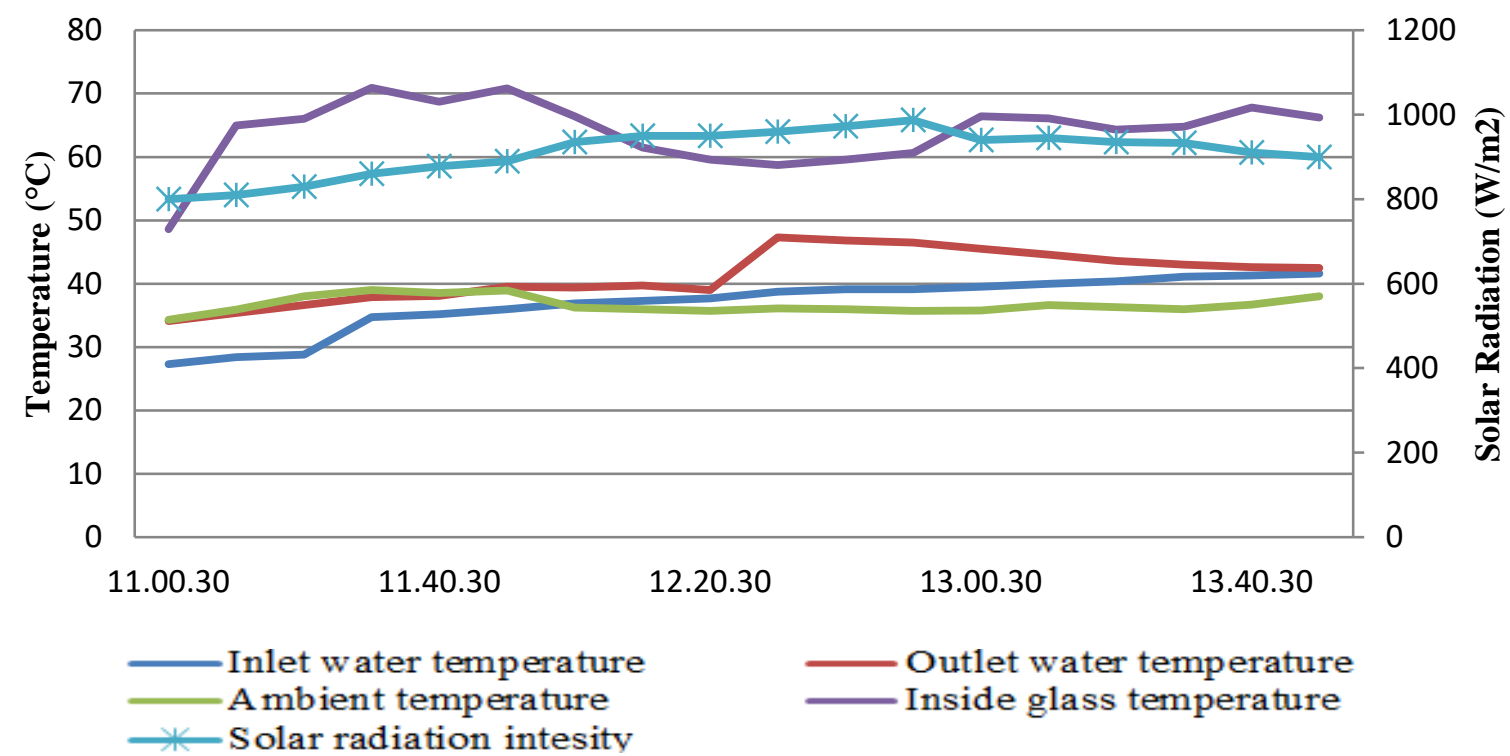

Figure 7 : Graph of the Average Intensity of Solar Radiation and Temperature obtained in the condition of Cloudy Weather

The last experiment was done with cloudy weather conditions on October 15 and 26, 2020, the resulting values; the maximum intensity of solar radiation only reached $960 \mathrm{Watt} / \mathrm{m} 2$ at 12.30 and the temperature of the outlet water was $38.3^{\circ} \mathrm{c}$. Then the minimum value reached $900 \mathrm{Watt} / \mathrm{m} 2$ at the end of data collection, it was because the weather was cloudy or the sun was covered by clouds, as we can see the results with Figure 7 above.

\section{CONCLUSION}

Based on the results of the research, it can be concluded that the water heater using the solar water heating system has been stated to be effective because radiation from sun rays to heat water has resulted in an average outlet water temperature of $40^{\circ} \mathrm{c}$. The result of the research in sunny weather condition was $46.8^{\circ} \mathrm{c}$ then the result of the research in the partly cloudy weather condition produced an outlet water temperature of $44.3^{\circ} \mathrm{C}$ and finally the result of data collection in the condition of cloudy weather was very different from the other two results, sunny or partly cloudy, which result obtained was $38.3^{\circ} \mathrm{C}$.

\section{REFERENCES}

[1] M. Sumarsono. Optimasi Jumlah Pipa-Pemanas Terhadap Kinerja. Jurnal Ilmiah Teknologi Energi. 2012;1(2): 46-55.

[2] V. B. Gawande, A. S. Dhoble, and D. B. Zodpe. CFD Analysis to Study Effect of Circular Vortex Generator Placed in Inlet Section to Investigate Heat Transfer Aspects of Solar Air Heater. Scientific World Journal.2014; 2014..

[3] W. Yaïci and E. Entchev, Performance Prediction of a Solar Thermal Energy System Using Artificial Neural Networks. Applied Thermal Engineering. 2014; 73(1): 1348-1359.

[4] Mohd Anas and Amin ,Md. Performance Study Of Solar Thermal Binary Power Cycles. Jurnal Mekanikal. 2011; 33(3): 56-69.

[5] C. E. Cong, S. Velautham, and A. N. Darus. Solar Thermal Organic Rankine Cycle As a Renewable Energy Option, Jurnal Mekanikal. 2005.

[6] E. Sciubba, Beyond Thermoeconomics? The Concept of Extended Exergy Accounting and its Application to the Analysis and Design of Thermal Systems. Exergy An International Journal. 2001; 
1(2): $68-84$

[7] A. Burhanuddin. Karakteristik Kolektor Surya Plat Datar Dengan Variasi Jarak Kaca Penutup Dan Sudut Kemiringan Kolektor. Universitas Sebelas Maret, 2006.

[8] Z. Chen, M. Gu, and D. Peng. Heat Transfer Performance Analysis of a Solar Flat-Plate Collector With an integrated Metal Foam Porous Structure Filled With Paraffin. Applied Thermal Engineering. 2010; 30(5): 1967-1973.

[9] S. A. Kalogirou. Solar Energy Engineering: Processes and Systems. Progress in Energy and Combustion Science. 2009.

[10] J. A. Duffie and W. A. Beckman. Wiley: Solar Engineering of Thermal Processes, 4th Edition - John A. Duffie, William A. Beckman. 2013.

[11] D. Zhou and C. Y. Zhao. Experimental Investigations on Heat Transfer in Phase Change Materials (PCMs) Embedded in Porous Materials. Applied Thermal Engineering. 2011;31(6): 970-977.

[12] H. Susanto and D. Irawan. Pengaruh Jarak Antara Pipa Pada Kolektor Terhadap Panas Yang Dihasilkan Solar Water Heater ( SWH ). Jurnal Teknik Mesin Univ. Muhammadiyah Metro.2017; 6(7): 84-91.

[13] Y. R. Sekhar, K. V Sharma, and M. B. Rao. Evaluation of Heat Loss Coefficients in Solar. ARPN Journal of engineering and applied sciences. 2009; 4(5): 15-19.

[14] A. Klevinskis and V. Bučinskas. Analysis of a Flat-Plate Solar Collector. Mokslas - Lietuvos ateitis. 2011; 3(3): 39-43.

[15] A. A. M. Sayigh, the Technology of Flat Plate Collectors. University of Waterloo, 1979.

[16] M. Sumarsono. Optimasi Jumlah Pipa-Pemanas Terhadap Kinerja. Jurnal Ilmiah Teknologi Energi, 2012;1(4): 46-55.

[17] S. A. Kalogirou. Solar thermal collectors and applications. Progress in Energy and Combustion Science. 2004; 30(3): 231-295.

[18] A. A. M. SAYIGH. Solar Energy Availability Prediction from Climatological Data. ACADEMIC PRESS, INC. 1977.

[19] R. Irawan. Pembuatan dan Pengujian Kolektor Surya Pelat Datar (FLAT-PLATE COLLECTORS) Kondisi STEADY berdasarkan Standar EN 12975. Universitas Lampung, 16AD.

[20] Y. Tian and C. Y. Zhao. A Numerical Investigation of Heat Transfer in Phase Change Materials (PCMs) Embedded in Porous Metals. Energy. 2011;36(9): 5539-5546.

[21] N. Ramadhan, S. Soeparman, and A. Widodo. Analisis Perpindahan Panas pada Kolektor Pemanas Air Tenaga Surya dengan Turbulence Enhancer. Jurnal Rekayasa Mesin. 2017; 8(1): 15-22.

[22] M. Edalatpour and J. P. Solano. Thermal-hydraulic Characteristics and Exergy Performance in Tubeon-Sheet Flat Plate Solar Collectors: Effects of Nanofluids and Mixed Convection. International Journal of Thermal Sciences. 2017; 118(6):397-409.

[23] N. G. Pratiwi, S. W. Hidayat, W. Ardiatna, and C. C. Putri. Comparison of K-Type and T-Type Thermocouples for Stability and Uniformity of Infant Incubator Temperature Testing Based on Iec 60601-2-19, Jurnal Standardisasi. 2019; 21(3): 211.

[24] E. R. Anugrah, R. Lapisa, and K. Arwizet. Heat Transfer Analysis in Heat Exchanger with Various Shifting Media Analisa. 2020;2(6):19-26,.

[25] H. M. Henning and J. Döll. Solar systems for Heating and Cooling of Buildings. Energy Procedia. 2012; 30(5):633-653. 